\title{
Dampak Inkubator Bisnis Terhadap Minat Berwirausaha Mahasiswa di Universitas Tridinanti Palembang
}

\section{The Impact of Business Incubator on Students Entrepreneurial Interest in Tridinanti University Palembang}

\author{
Veny Mayasari, Liliana \& Agung Anggoro Seto*
}

Jurusan Manajemen, Fakultas Ekonomi, Universitas Tridinanti Palembang, Indonesia

*Coresponding Email: agung.anggoro.seto@univ-tridinanti.ac.id

\begin{abstract}
Abstrak
Penelitian ini bertujuan untuk mengetahui dampak kegiatan inkubator bisnis terhadap minat berwirausaha mahasiswa di Universitas Tridinanti. Jenis penelitian ini adalah komparatif. Populasi pada penelitian ini berjumlah 5.737 orang. Teknik pengambilan sampel menggunakan Accidental sampling dengan jumlah sampel ditentukan sebanyak 200 responden. Sumber data primer dengan teknik pengumpulan data menggunakan kuesioner, wawancara dan observasi. Teknik analisis data menggunakan paired sample $t$ test. Hasil penelitian menunjukkan bahwa terdapat perbedaan minat berwirausaha mahasiswa sebelum dan sesudah mengikuti kegiatan inkubator bisnis dengan nilai signifikansi sebesar 0,000 di mana nilai rata-rata minat berwirausaha mahasiswa setelah mengikuti kegiatan inkubator bisnis meningkat sebesar 1,960 point dibandingkan sebelum mengikuti kegiatan inkubator bisnis. Hasil penelitian juga menemukan bahwa kegiatan inkubator bisnis telah mengubah pola pikir sebagian mahasiswa.
\end{abstract}

Kata kunci: Inkubator, Minat, Wirausaha, Bisnis.

\begin{abstract}
This research aims to find out the impact of business incubator activities against the interests of student entrepreneurship at the University of Tridinanti. This type of research is comparative. The population are 5,737 people. Sampling techniques using Accidental sampling by the number of samples was determined as many as 200 respondents. The primary data sources with the techniques of data collection using the questionnaire, interview and observation. Data analysis techniques using paired sample t test. The results showed that there is a difference of interest a student entrepreneurship before and after follow the business incubator activities with significance value of 0.000 where the average value of interest in entrepreneurship student business incubator activities after following increased by 1.960 point than before following the activities of the business incubator. The research also found that business incubator activities have changed the mindset of most college students.
\end{abstract}

Keywords: Incubators, Interest, Entrepreneur, Business

Keywords: Incubators, Interest, Entrepreneur, Business

How to Cite : Mayasari, V., Liliana2 \& Seto, A. A, (2019)Dampak Inkubator Bisnis Terhadap Minat Berwirausaha Mahasiswa, Jurnal Konsep Bisnis dan Manajemen 6 (1) : 13-23 


\section{PENDAHULUAN}

Salah satu tujuan terbentuknya suatu negara adalah untuk mensejahterakan masyarakat, ukuran kesejahteraan masyarakat dapat dilihat dari besarnya pendapatan per kapita suatu negara yang tidak bisa dilepaskan dari jumlah dan pertumbuhan wirausaha negara tersebut.

Global Entrepreneur Index mencatat 10 besar negara yang memiliki pendapatan kapita terbesar adalah negara dengan pertumbuhan wirausaha. Global Entrepreneur Index (2015) juga mencatat bahwa Indonesia hanya menempati peringkat 120 dari 130 negara dengan angka index yang hanya 21,0 . Hal ini menunjukkan bahwa pertumbuhan wirausaha di Indonesia telah tertinggal dari negara lain di dunia.

Berbagai upaya telah dilakukan pemerintah untuk memotivasi masyarakat agar tertarik untuk berwirausaha seperti pemberian bantuan dana dan kredit berbiaya rendah dengan berbagai skim, baik bagi wirausaha, calon wirausaha maupun bagi mahasiswa sebagai generasi muda yang diharapkan dapat menjadi bibit calon wirausaha di masa yang akan datang. Namun sampai saat ini jumlah wirausaha di Indonesia secara keseluruhan belum mengalami peningkatan yang cukup signifikan.
Jika dikaji lebih mendalam, rendahnya minat berwirausaha bukan hanya menjadi tanggung jawab pemerintah namun juga menjadi tanggung jawab lembaga pendidikan seperti perguruan tinggi. Salah Satu Perguruan Tinggi yang menyadari pentingnya keberadaan wirausaha untuk mendukung perekonomian yaitu Universitas Tridinanti Palembang. Selain memasukkan kewirausahaan sebagai mata kuliah wajib di setiap program studi, Universitas Tridinanti juga rutin menyelenggarakan Inkubator bisnis yang wajib diikuti oleh setiap mahasiswa secara berkelompok.

Inkubator bisnis merupakan suatu wahana transformasi pembentukan sumber daya manusia yang tidak atau kurang kreatif dan produktif menjadi sumber daya manusia yang memiliki motivasi berwirausaha secara kreatif, inovatif, produktif dan kooperatif sebagai langkah awal dari pencapaian wirausaha yang memiliki keunggulan kompetitif dan komparatif serta memiliki visi dan misi (Agustina, 2011).

Melalui inkubator bisnis, setiap kelompok mahasiswa dituntut untuk mampu menemukan ide bisnis, menuangkannya dalam bentuk produk/jasa, mempromosikan dan memasarkannya, mengevaluasi serta menyusun rencana berkelanjutan dari bisnis tersebut. Namun meskipun telah diwajibkan, tidak semua maha- 
siswa berminat untuk benar-benar memulai merintis menjadi seorang wirausaha pasca kegiatan inkubator bisnis, sebagian mahasiswa hanya mengikuti kegiatan inkubator bisnis hanya untuk memenuhi kewajiban tugas praktikum mata kuliah kewirausahaan sehingga keberhasilan kegiatan inkubator bisnis yang dijalankan oleh Universitas Tridinanti Palembang belum sepenuhnya terukur.

Beberapa penelitian terdahulu mengenai inkubator bisnis pernah dilakukan oleh Panggabean (2005) dan Supangat (2005) di mana penelitiannya menemukan bahwa inkubator bisnis berperan terhadap penciptaan wirausaha baru. Sedangkan Agustina (2011) dan Sanjaya (2011) menemukan bahwa inkubator bisnis dapat meminimalkan risiko bagi kegagalan wirausaha baru, sedangkan Purwaningsih dkk. (2017) menemukan bahwa inkubator bisnis menjadi salah satu model penciptaan wirausaha di kalangan pelajar, namun belum ada penelitian yang membandingkan minat mahasiswa sebelum dan sesudah mengikuti inkubator bisnis.

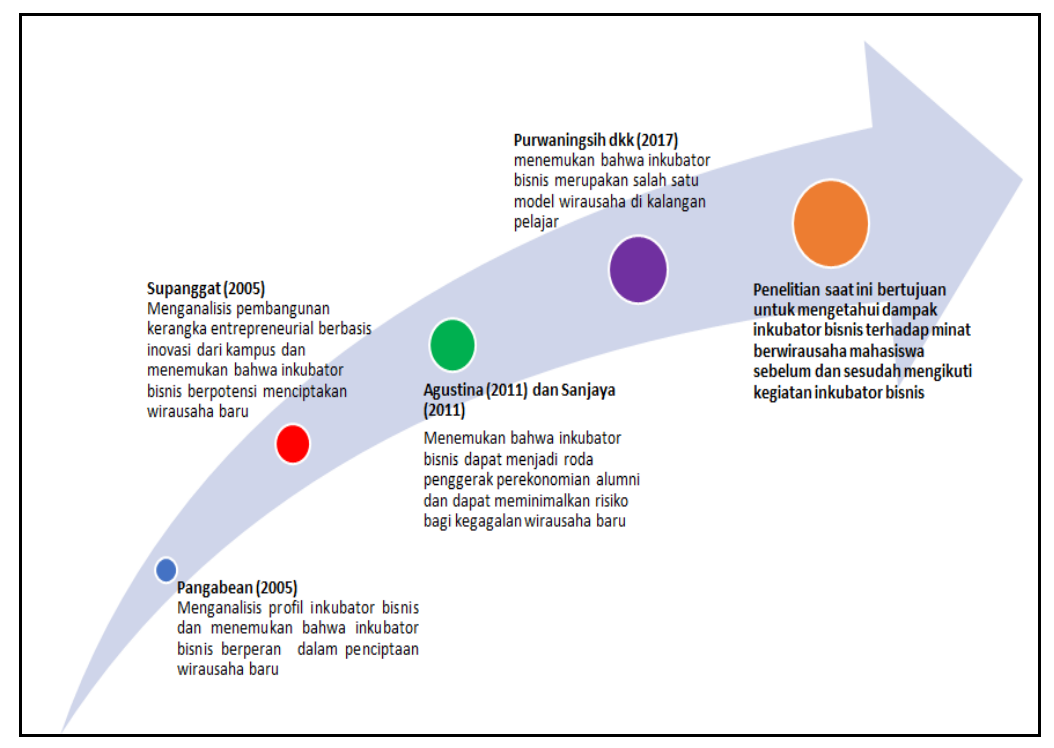

Gambar 1. Road Map Penelitian

Penelitian yang mengukur dampak berwirausaha mahasiswa di Indonesia kegiatan inkubator bisnis terhadap minat khususnya maupun Universitas Tridinanti sebelum dan sesudah mengikuti kegiatan Palembang khususnya. Kajian ini penting tersebut sangat penting dilakukan untuk dilakukan untuk memperoleh gambaran mengukur keberhasilan inkubator bisnis yang lebih mendalam mengenai dampak sebagai model untuk meningkatkan minat inkubator bisnis terhadap minat maha- 
siswa Universitas Tridinanti Palembang untuk berwirausaha sehingga dari penelitian ini diharapakan nantinya dapat dirumuskan model kegiatan inkubator bisnis yang ideal dan efektif untuk meningkatkan minat berwirausaha mahasiswa di Universitas Tridinanti Palembang khususnya dan Universitas-universitas lainnya di Indonesia sehingga dapat mencetak wirausahawirausaha muda yang benar-benar siap bersaing dalam dunia bisnis.

Menurut Seto dan Septianti (2018) minat adalah kondisi di mana individu memusatkan seluruh perhatiannya pada suatu objek tertentu dengan perasaan senang. Minat juga dapat diartikan sebagai ketertarikan seseorang akan suatu hal (Seto, 2018). Sedangkan wirausaha dapat diartikan sebagai sebuah kemampuan (an ability) yang di dalamnya termasuk dalam artian 'usaha' (effort), aktivitas, aksi, tindakan dan lain sebagainya untuk menyelesaikan suatu tugas (task) (Frinces, 2010).

Minat berwirausaha dapat didefinisikan sebagai keinginan, keingintahuan, ketertarikan, serta kesediaan seseorang untuk bekerja keras, mandiri, berani mengambil resiko maupun menghadapi tantangan dalam keterbatasan, dengan bertindak kreatif guna memenuhi kebutuhan hidupnya serta kemajuan usahanya (Marini dan Hamidah, 2014). Minat ber- wirausaha juga dapat diartikan sebagai ketertarikan seseorang untuk menciptakan suatu usaha dengan kemampuan yang dimiliki dan berani mengambil risiko. Minat berwirausaha timbul karena adanya perasaan senang, perhatian, dukungan lingkungan dan pengalaman dan umumnya minat berwirausaha diukur melalui faktor sosial, ekonomi dan psikis seseorang (Evaliana, 2015).

Musanto (2004) mengungkapkan bahwa kampus adalah agen penting perubahan masa depan Bangsa. Kampus memiliki peran yang tak tergantikan dalam menciptakan budaya wirausaha di Indonesia dan sekaligus sebagai pembentukan dan pelatihan entrepreneur baru melalui inkubator bisnis.

Supangkat, dkk (2005), Agustina (2011) menjelaskan bahwa konsep inkubator bisnis di Perguruan tinggi berpotensi besar untuk menciptakan wirausahawirausaha baru melalui program Inkubator Bisnis sebagai wujud Dharma Perguruan Tinggi dalam melakukan penelitian dan pengabdian kepada masyarakat. Aktivitas - aktivitas dari penelitian dan pengabdian masyarakat diharapkan mampu mengubah penemuan-penemuan menjadi inovasi sehingga terjadi proses penciptaan nilai (value creation). 


\section{METODE PENELITIAN}

Jenis penelitian ini adalah deskriptif komparatif. Populasi dalam penelitian ini adalah seluruh mahasiswa di Universitas Tridinanti Palembang yang berjumlah 5.737 mahasiswa, Teknik pengambilan sampel yaitu Accidental Sampling yaitu teknik pengambilan sampel yang dilakukan secara kebetulan artinya siapapun populasi yang ditemui penulis pada saat dilakukan penelitian maka dapat dijadikan sampel penelitian. Jumlah sampel ditentukan sebanyak 200 responden.

Model analisis data yang digunakan dalam penelitian ini adalah analisis kualitatif dan kuantitatif. Variabel penelitian menggunakan variabel tunggal yaitu minat berwirausaha dengan indikator faktor sosial, ekonomi dan psikis.

Teknik analisis data yang digunakan pada penelitian menggunakan uji beda dua sample yang berpasangan (paired sample ttest). Uji paired sampel t-test digunakan untuk mengetahui ada atau tidaknya perbedaan minat berwirausaha mahasiswa sebelum dan setelah mengikuti inkubator bisnis. Adapun langkah-langkah teknik analisis data pada penelitian ini adalah sebagai berikut:

1) Uji Instrumen Penelitian yang terdiri dari uji Validitas dan Realibilitas yang digunakan untuk mengukur apakah suatu kuesioner dikatakan sah dan realibel untuk suatu model penelitian. Kriteria penerimaan uji validitas yaitu apabila r-hitung > r-tabel, sedangkan kriteria penerimaan untuk uji realibilitas yaitu apabila nilai Cronbach Alpha $>0,6$.

2) Uji Normalitas

Bertujuan untuk menguji apakah dalam sebuah model regresi, variabel dependen, variabel independen, atau keduanya mempunyai distribusi normal atau tidak.

Dasar pengambilan keputusan :

Jika probabilitasnya (nilai sig) $>0,05$ maka Ho diterima Jika probabilitasnya (nilai sig) $\leq 0,05$ maka Ho ditolak

3) Uji beda sampel berpasangan (Uji Paired Sampel t-test). Uji ini digunakan untuk mengetahui ada atau tidaknya perbedaan minat berwirausaha mahasiswa di Universitas Tridinanti Palembang sebelum dan sesudah kegiatan inkubator bisnis. Dengan kriteria penerimaan sebagai berikut :

- Ho diterima jika - $\mathrm{t}$ tabel $\leq \mathrm{t}$ hitung $\leq$ t tabel.

- Ho ditolak jika - t hitung < -t tabel atau thitung $>\mathrm{t}$ tabel.

Teknik pengumpulan data pada penelitian ini menggunakan data primer dan 
data sekunder. Metode Pengumpulan data rausaha Mahasiswa di Universitas Tridipada penelitian ini yaitu obesevasi, wawan- nanti Palembang.

cara dan dokumentasi yang berhubungan

dengan inkubator bisnis dan minat berwi-

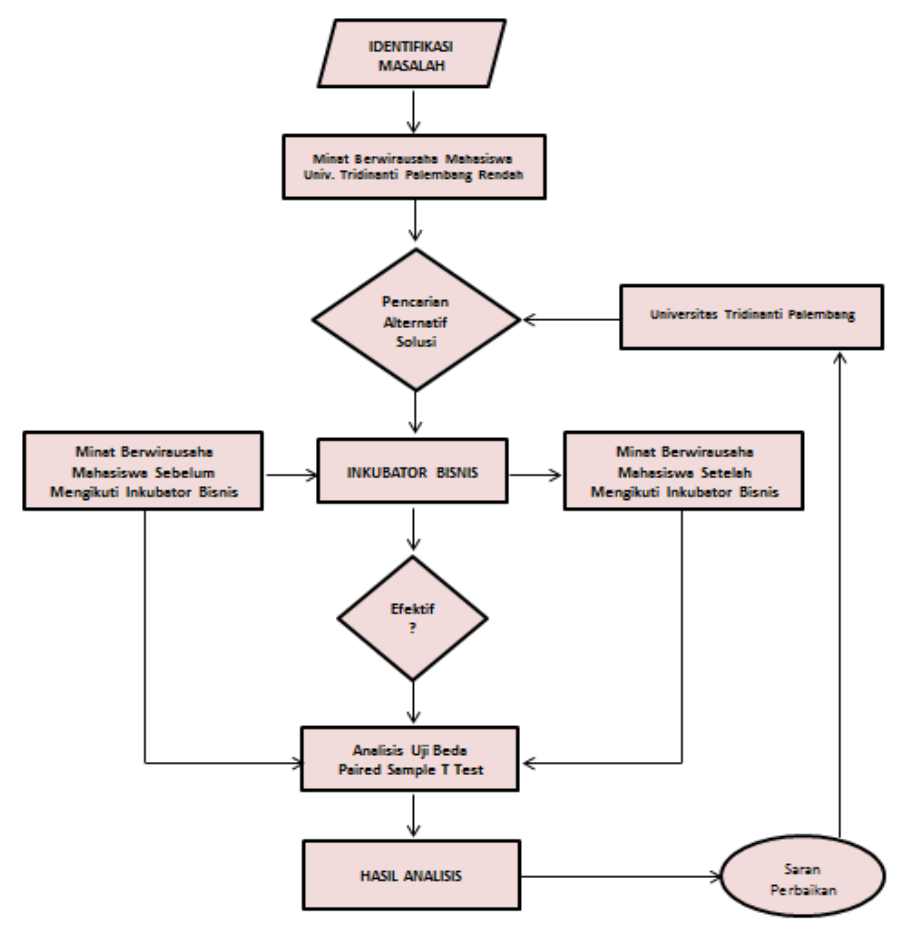

Gambar 2. Tahapan Penelitian

\section{HASIL DAN PEMBAHASAN}

Untuk menjawab rumusan masalah yang telah disusun, maka perlu dilakukan kajian untuk membahas hasil penelitian. Berdasarkan hasil penelitian didapat karakteristik responden sebagai berikut :

Tabel 1. Karakteristik Responden

\begin{tabular}{|c|c|c|c|}
\hline Karakteristik & Kelompok & Total & Persentase \\
\hline \multirow{3}{*}{ Jenis Kelamin } & Laki-laki & 73 & $36,5 \%$ \\
\hline & Perempuan & 127 & $63,5 \%$ \\
\hline & Total & 200 & $100 \%$ \\
\hline \multirow{4}{*}{ Usia } & $\leq 20$ tahun & 21 & $10,5 \%$ \\
\hline & $21-30$ tahun & 176 & $88,0 \%$ \\
\hline & $>30$ tahun & 3 & $1,5 \%$ \\
\hline & Total & 200 & $100 \%$ \\
\hline \multirow{5}{*}{ Fakultas } & Ekonomi & 171 & $85,5 \%$ \\
\hline & FKIP & 16 & $8,0 \%$ \\
\hline & Teknik & 9 & $4,5 \%$ \\
\hline & Pertanian & 4 & $2,0 \%$ \\
\hline & Total & 200 & $100 \%$ \\
\hline \multirow{3}{*}{$\begin{array}{l}\text { Telah Memiliki atau akan menjalankan } \\
\text { Usaha/Bisnis? }\end{array}$} & $\mathrm{Ya}$ & 21 & $10,5 \%$ \\
\hline & Tidak & 179 & $89,5 \%$ \\
\hline & Total & 200 & $100 \%$ \\
\hline
\end{tabular}


Tabel 1 menunjukkan bahwa jika dili- Fakultas Keguruan dan Ilmu Pendidikan hat dari jenis kelamin, mayoritas respon- (FKIP), 4,5\% dari Fakultas Teknik dan 2\% den pada penelitian ini adalah perempuan dari Fakultas Pertanian. Untuk mengetahui yaitu sebanyak 63,5\%, sisanya 36,5\% ada- minat awal responden mengenai wirausaha lah laki-laki. Responden pada penelitian ini pada kuesioner ditanyakan apakah responjuga didominasi oleh responden berusia den telah memiliki atau akan menjalankan muda dengan rentang usia 21-30 tahun se- usaha/bisnis, mayoritas responden menbanyak $88 \%$, sisanya $10,5 \%$ berusia $\geq 20$ jawab tidak $(89,5 \%)$. Responden yang telah tahun dan $1,5 \%$ berusia $>30$ tahun. memiliki atau telah berminat akan menja-

Jika dilihat dari asal fakultas respon- lankan usaha/bisnis hanya 10,5\%. den, mayoritas responden merupakan maHasil uji instrumen penelitian dengan hasiswa yang berasal dari fakultas ekonomi menggunakan uji validitas dan uji reliasebanyak 85,5\%, sisanya $8 \%$ berasal dari bilitas didapat hasil sebagai berikut:

Tabel 2. Hasil Uji Validitas

\begin{tabular}{|c|c|c|c|c|}
\hline Variabel & Butir & r-hitung & r-tabel & Keterangan \\
\hline \multirow{6}{*}{$\begin{array}{l}\text { Minat Berwirausaha Sebelum } \\
\text { Mengikuti Inkubator Bisnis } \\
\qquad\left(\mathrm{X}_{1}\right)\end{array}$} & 1 & 0,698 & 0,138 & Valid \\
\hline & 2 & 0,763 & 0,138 & Valid \\
\hline & 3 & 0,752 & 0,138 & Valid \\
\hline & 4 & 0,791 & 0,138 & Valid \\
\hline & 5 & 0,820 & 0,138 & Valid \\
\hline & 6 & 0,812 & 0,138 & Valid \\
\hline \multirow{6}{*}{$\begin{array}{l}\text { Minat Berwirausaha Setelah } \\
\text { Mengikuti Inkubator Bisnis } \\
\qquad\left(\mathrm{X}_{1}\right)\end{array}$} & 1 & 0,694 & 0,138 & Valid \\
\hline & 2 & 0,766 & 0,138 & Valid \\
\hline & 3 & 0,754 & 0,138 & Valid \\
\hline & 4 & 0,790 & 0,138 & Valid \\
\hline & 5 & 0,822 & 0,138 & Valid \\
\hline & 6 & 0,813 & 0,138 & Valid \\
\hline
\end{tabular}

Sumber : Data Primer Diolah (2019)

Tabel 3. Hasil Uji Realibilitas Variabel Penelitian

\begin{tabular}{clcccc}
\hline No & \multicolumn{1}{c}{ Variabel } & Cronbach's Alpha & N of Items & Keterangan \\
\hline 1 & $\begin{array}{l}\text { Minat Berwirausaha Sebelum } \\
\text { Mengikuti Inkubator Bisnis }\end{array}$ & 0,873 & 6 & Realibel \\
\hline 2 & $\begin{array}{l}\text { Minat Berwirausaha Sesudah } \\
\text { Mengikuti Inkubator Bisnis }\end{array}$ & 0,873 & 6 & Realibel \\
\hline
\end{tabular}

Berdasarkan hasil pengujian pada Ta- tabel $(0,138)$, dengan demikian seluruh bubel 2 menunjukkan bahwa semua butir per- tir instrumen dinyatakan valid pada taraf nyataan instrumen Minat Berwirausaha nyata 5\%. yang diajukan memiliki nilai $r$-hitung $>$ r- 
Sedangkan hasil uji realibilitas pada Tabel 3 menunjukkan bahwa variabel yang diujikan memiliki nilai alpha cronbach lebih besar dari 0,6, dimana nilai cronbach's alpha > 0,6 menunjukkan bahwa semua variabel realibel.

Setelah dilakukan uji validitas dan uji realibilitas, selanjutnya dilakukan uji normalitas yang bertujuan untuk menguji kuesioner, apakah berdistribusi normal atau tidak. Uji normalitas untuk penelitian ini dilakukan dengan melakukan uji Kolmogorov Smirnov. Berikut ini hasil uji normalitas pada penelitian ini.

Tabel 4. Hasil Uji Kolmogorov Smirnov

\begin{tabular}{lrrr}
\hline & \multicolumn{3}{c}{ Kolmogorov-Smirnov $^{\mathrm{a}}$} \\
\hline Minat Berwirausaha Setelah Inkubator & Statistic & Df & Sig. \\
\hline Minat Berwirausaha Sebelum Inkubator & .061 & 200 & .070 \\
\hline
\end{tabular}

Berdasarkan hasil uji normalitas pada Tabel 4 di dapat hasil Signifikansi sebesar 0,070 pada variabel minat berwirausaha setelah inkubator bisnis dan 0,063 pada variabel minat berwirausaha mahasiswa sebelum inkubator bisnis. Nilai Sig 0,070 dan 0,063 ini > 0,05 yang artinya bahwa data pada penelitian ini berdistribusi normal. Untuk menjawab rumusan masalah 5 sebagai berikut: penelitian, maka dilakukan uji hipotesis. Uji hipotesis pada penelitian ini bertujuan untuk mencari tahu ada atau tidaknya perbedaan minat berwirausaha mahasiswa sebelum dan setelah mengikuti kegiatan inkubator bisnis. Uji hipotesis pada penelitian ini mengunakan uji paired sampel $t$ test. Adapun hasil uji paired sampel t test pada penelitian ini dapat dilihat pada Tabel

Tabel 5. Hasil Uji Paired Sample t-test

\begin{tabular}{cccccc}
\hline \multicolumn{7}{c}{ Paired Differences } \\
\hline & & & & \\
& & Mean & $t$ & Df & Sig. (2-tailed) \\
\hline Pair 1 & Sesudah - Sebelum & 1.960 & 49.000 & 199 & .000 \\
\hline
\end{tabular}

Tabel 5 menunjukkan bahwa terdapat sebelum mengikuti kegiatan. $t$ hitung seselisih rata-rata minat mahasiswa sesudah besar 49,000 dan nilai signifikansi sebesar dan sebelum mengikuti kegiatan inkubator 0,000 . Nilai signifikansi sebesar 0,000 atau bisnis sebesar 1,960, di mana minat ber- lebih kecil dari 0,05, hal ini berarti Ho wirausaha sesudah mengikuti kegiatan (hipotesis awal) ditolak dan Ha (hipotesis inkubator bisnis lebih tinggi dibandingkan alternatif) diterima yang artinya bahwa 
terdapat perbedaan minat berwirausaha pada mahasiswa di Universitas Tridinanti Palembang sebelum dan sesudah mengikuti kegiatan inkubator bisnis. Hal ini juga berarti kegiatan inkubator bisnis secara signifikan berdampak pada peningkatan minat berwirausaha mahasiswa di Universitas Tridinanti Palembang.

Adanya perbedaan minat berwirausaha sebelum dan sesudah kegiatan inkubator bisnis disebabkan oleh kegiatan inkubator bisnis sedikit banyak telah mengubah pola pikir sebagian mahasiswa yang sebelumnya apatis terhadap kegiatan inkubator bisnis. Proses perubahan pola pikir tersebut berdasarkan hasil observasi dan wawancara setidaknya terjadi melalui dua cara yaitu :

a. Melalui teman satu kelompok yang telah memulai bisnis

Mahasiwa yang sebelumnya apatis dan sedikit terpaksa (karena merupakan kewajiban mata kuliah) dalam mengikuti kegiatan inkubator bisnis menjadi tertarik untuk memulai bisnis dan berwirausaha karena melihat teman satu kelompoknya menampilkan ide bisnisnya. Berawal dari sekedar membantu proses produksi/pembuatan barang yang akan dijual pada kegiatan inkubator bisnis, yang menimbulkan keyakinan mampu melakukan hal ter- sebut kemudian setelah kegiatan inkubator bisnis berkeinginan suatu saat mencoba bisnis tersebut. Hal ini sejalan dengan hasil kajian yang dilakukan Seto (2017) yang menyatakan lingkungan dapat mempengaruhi minat dan hal ini sejalan juga dengan kajian yang dilakukan Aditia (2012) di mana dinyatakan bahwa teman sekelas atau teman sekolah, dapat mempengaruhi minat siswa untuk berwirausaha melalui dorongan, contoh maupun kegiatan diskusi.

b. Melalui antusisme khalayak kampus yang membeli ataupun menggunakan produk/jasa yang ditawarkan.

Khalayak kampus baik itu rekan sesama mahasiswa, pegawai maupun dosen sedikit banyak telah mengubah pola pikir mahasiswa yang sebelumnya tidak memiliki keinginan berwirausaha menjadi sangat ingin melanjutkan bisnis yang dibuatnya meskipun kegiatan inkubator bisnis telah ber-akhir. Proses pengubahan pola pikir itu dimulai dengan sangat antusiasnya rekan sesama mahasiswa, dosen ataupun karyawan yang membeli makanan yang dibuat dan dijual oleh mahasiswa tersebut, sehingga tanpa disadari stok makanan habis dan timbul order atau pesanan untuk esok hari. Proses ini tanpa disa- 
dari telah membangun kepercayaan diri maha-siswa maupun kelompok mahasiswa tersebut bahwa makanan yang mereka buat secara coba-coba la$\mathrm{ku}$ “dipasaran". Sehingga pada hari penutupan sebagian mahasiswa tertarik dan penasaran untuk mencoba berwirausaha dan memasarkan makanan buatan mereka diluar kegiatan inkubator bisnis.

Adanya perubahan pola pikir yang meningkatkan minat berwirausaha mahasiswa yang berasal dari teman satu kelompok maupun antusiasme khalayak/ lingkungan kampus melalui kegiatan inkubator bisnis yang pada akhirnya menghasilkan perbedaan minat berwiusaha sebelum dan sesudah kegiatan inkubator bisnis ini sejalan dengan teori yang diungkapkan oleh Sarifudin (2011) yang menyatakan bahwa lembaga pendidikan menjadi salah satu institusi yang mempunyai peranan penting dalam upaya melahirkan wirausaha yang tangguh. Selain melalui pembelajaran kewirausahaan, lingkungan kampus yang mendukung akan mendorong tumbuhnya minat berwirausaha. Hasil penelitian ini juga sejalan dengan hasil penelitian Salem (2014), Lasrado et. al (2016) serta Patton dan Marlow (2011) yang mengungkapkan bahwa inkubator bisnis mampu meningkatkan intensi berwirausaha serta me-nambah keunggulan kompetitif pengusaha muda yang dapat berpengaruh terhadap pertumbuhan dan pembangunan ekonomi.

\section{SIMPULAN}

Hasil penelitian menunjukkan bahwa terdapat perbedaan minat berwirausaha mahasiswa di Universitas Trdinanti Palembang sebelum dan sesudah mengikuti kegiatan inkubator bisnis dengan nilai signifikansi uji paired sample t test sebesar 0,000 di mana nilai rata-rata minat mahasiswa setelah mengikuti kegiatan inkubator bisnis meningkat atau lebih besar 1,960 point dibandingkan sebelum mengikuti kegiatan inkubator bisnis.

Adanya perbedaan minat berwirausaha sebelum dan sesudah kegiatan inkubator bisnis disebabkan oleh kegiatan inkubator bisnis sedikit banyak telah mengubah pola pikir sebagian mahasiswa yang sebelumnya apatis terhadap kegiatan inkubator bisnis. Proses perubahan pola pikir tersebut terjadi melalui dua cara yaitu melalui atau kelompok yang telah memulai bisnis dan melalui antusiasme khalayak kampus dalam membeli produk/ jasa yang ditawarkan.

\section{UCAPAN TERIMAKASIH}

Ucapan terimakasih tim penulis ucapkan kepada Direktorat Riset dan Pengabdian Kepada Masyarakat (DRPM) Kementerian Riset dan Pendidikan Tinggi yang telah membiayai penelitian ini me-alui skim Penelitian Dosen Pemula (PDP). 


\section{DAFTAR PUSTAKA}

Aditia, Rano. (2012). Faktor-faktor Penentu Minat Mahasiswa Manajemen untuk Berwirausaha (Studi Mahasiswa Manajemen FE UN Padang). Jurnal Manajemen, 1(1).

Agustina, T. S. (2011). Peran Inkubator Bisnis Perguruan Tinggi dalam Meminimalkan Resiko Kegagalan bagi Wirausaha Baru pada Tahap Awal (start-up). Jurnal Ekonomi dan Bisnis Airlangga (JEBA)/ Journal of Economics and Business Airlangga, 21(1).

Aprilianty, E. (2012). Pengaruh Kepribadian Wirausaha, Pengetahuan Kewirausahaan, dan Lingkungan terhadap Minat Berwirausaha Siswa SMK. Jurnal Pendidikan Vokasi, 2(3).

Evaliana, Y. (2015). Pengaruh Efikasi Diri dan Lingkungan Keluarga Terhadap Minat Berwirausaha Siswa. JPBM (Jurnal Pendidikan Bisnis dan Manajemen), 1(1), 53-60.

Frinces, Z. H. (2010). Pentingnya Profesi Wirausaha di Indonesia. Jurnal ekonomi dan pendidikan, 7(1).

Global Entrepreneur Index. (2015). Global Entrepreneurship and Development Index 2015. Edward Elgar Publishing.

Lasrado, V., Sivo, S., Ford, C., O'Neal, T., \& Garibay, I. (2016). Do graduated university incubator firms benefit from their relationship with university incubators?.The Journal of Technology Transfer, 41(2), 205-219.

Marini, C. K., \& Hamidah, S. (2014). Pengaruh SelfEfficacy, Lingkungan Keluarga, dan Lingkungan Sekolah Terhadap Minat Berwirausaha Siswa SMK Jasa Boga. Jurnal Pendidikan Vokasi, 4(2).

Musanto, Trisno (2004). Peran Pro Aktif Perguruan Tinggi Dalam Mengembangkan Usaha Kecil dan Desa Binaan. Majalah Ekonomi Universitas Airlangga Tahun XIV, No.3. Desember 2004.

Panggabean, R. (2005). Profil Inkubator dalam Penciptaan Wirausaha Baru. Jakarta: Kementerian UMKM.

Patton, D., \& Marlow, S. (2011). University technology business incubators: helping new entrepreneurial firms to learn to grow. Environment and Planning C: Government and Policy, 29(5), 911-926.
Purwaningsih, A., Herawati, A., Pudianti, A., \& Septiari, E. D. (2017). Crafting a Model of Student Entrepreneurs through Business Incubators. Review of Integrative Business and Economics Research, 6(2), 312.

Salem, M. I. (2014). The Role Of Universities In Building A Knowledge-Based Economy In Saudi Arabia. International Business \& Economics Research Journal (IBER), 13(5), 1047-1056. https://doi.org/10.19030/iber.v13i5.877.

Sanjaya, B. A. (2011). Inkubator Bisnis Sebagai Penggerak Roda Perekonomian Alumni. Jurnal Eksos, 2 (1), 63-75.

Sarifudin, Anis . (2011). Membangun Jiwa Wirausaha Siswa SMK. Diakses 26/9 2013 dari http://aniesmedia.blogspot. com/2011/04/membangun-jiwa-wirausahasiswa-smk.html.

Seto, A. A. (2018). Pengantar Manajemen. Agung Anggoro Seto.

Seto, A. A. (2017, November). Regulasi dan Motivasi Terhadap Minat Menjadi Dosen Pada Perguruan Tinggi Swasta di Kota Palembang. In Prosiding Seminar Nasional Darmajaya (Vol. 1, No. 1, pp. 165-175).

Seto, A. A., \& Septianti, D. (2018). Pengaruh Kompensasi, Motivasi dan Kompetensi Terhadap Minat Melakukan Penelitian pada Dosen di Universitas Tridinanti Palembang. Seminar Nasional Sistem Informasi (SENASIF) (Vol. 2, No. 1, pp. 1479-1486).

Supangat, Suhono Harso. (2005). Tahapan Pembentukan Inkubator Bisnis. Bandung : Seminar Nasional Promoting Local Economy Through Business Incubation. Institut Teknologi Bandung, 22 Desember, Bandung.

Supangkat, Suhono Harso dkk. (2005). New Enterprise Berbasis Inovasi dari Kampus Dalam Kerangka Entrepreneurial Economic Development. Bandung : Pusat Inkubator Bisnis-ITB. 